\title{
Contributions to the knowledge of American Ectrichodiinae III. The genus Cricetopareis Breddin, 1903 (Hemiptera: Reduviidae)'
}

\author{
Domingo J. Carpintero ${ }^{2}$ and Jenaro Maldonado-Capriles ${ }^{s}$
}

ABSTRACT

The authors give morphological notes, observations on the biology, and provide keys to the species in Cricefopareis. C. brasiliensis, a new species, is described and illustrated.

\section{RESUMEN}

Contribuciones al conocimiento de los ectricodinos americanos.

III. El género Cricetopareis Breddin, 1903

Se redescribe el género Cricetopareis y se proveen claves para los machos y las hembras a base de las características genitales. Se describe e ilustra la nueva especie $C$. brasiliensis.

\section{INTRODUCTION}

The authors continue the study of American Ectrichodiinae with a monographic study of the small American genus Cricetopareis. We were fortunate in having at hand all the species for comparative studies. The type material is deposited in the collection of the Royal Institute of Natural Sciences (RINS) at Tervuren, Belgium. Measurements are given in millimeters.

Descriptions and discussion

Cricetopareis Breddin, 1903

1903 Cricetopareis Breddin, 18:65

Type species: Ectrichodia tucumana Berg, 1884:191. By original designation. Fixed by Breddin 1903, 18:66.

${ }^{1}$ Manuscript submitted to Editorial Board 10 May 1990.

¿Sanitary Arthropodology, Sanitation Department, Instituto Malbrán, Vélez Sarsfield 563, Buenos Aires, Argentina.

${ }^{3}$ Entonomogist, Department of Plant Protection.

4 The authors are grateful to Dr. L. Baert, from RINS, for the loan of specimens that included the new species herein described; and the Department of Plant Protection, University of Puerto Rico, Mayagüez, P.R.

${ }^{5}$ Breddin, G., 1903. Einige neue sudamerikanische Ectrichodiinen. Soc. Entomol. 28: 65-66. 
Breddin's description is translated and slightly modified as follows: "Eyes very large, larger in the male; eyes in the female as wide as long, in the male wider than long. Head wide and relatively short, strongly constricted behind eyes, with a relatively short, narrow neck. Ocellar callus quite elevated. Vertex flat, from interocular suture strongly declivitous towards apex, surface finely transversely corrugate, between eyes and reaching antenniferous tubercles, rows of coarser short crossstriations. Antenna with 8 segments. Beneath, convex between eyes, strongly swollen ventro-laterally behind eyes, forming pouches that are visible from above. Second rostral segment subequal in length to first, not swollen; third segment the shortest.

Pronotum trapezoidal. Very short collar; transverse sulcus closer to anterior margin, interrupted on both sides of the median line by a flattened, quadrangular carina (fig. 6); longitudinal sulcus on anterior lobe not reaching posterior lobe, interrupted by the mentioned carina. Posterior border roundly sloping to margin, posterior margin broadly and moderately convex. Abdominal sterna punctate, last sternum punctate along margins only. Intersternal sutures crenate-punctate. Legs with short spongy fossa, about one tenth as long as corresponding leg. Males fully alate or macropterous, females braquipterous or sub-braquipterous.

Morphologically belongs between Mindarus (Brontostoma) and Rhiginia. Differs from the latter by having large eyes, crenate-punctate intersternal sutures, and punctate abdominal sterna. These characters also separate it from Mindarus." Carpintero ${ }^{6}$ considered Breddin's definition quite complete and added that the ventro-lateral pouches behind eyes occur in both sexes and the very large, some times subpedunculate eyes, especially in the males, do not occur in other American genera. Breddin did not describe the tylus.

Cricetopareis differs from the American ectrichodiines by the following set of characters:

1. Quite broad and short head. Large, sometimes subpedunculate eyes (males). Large and strongly elevated ocellar callus. Tylus elevated, triangular.

2. Antenniferous tubercle thick, inserted on anterior margin of eye. First antennal segment surpassing apex of head by almost half its own length. Antenna 8 -segmented.

3. Rostrum thick, I and II segments subequal in length.

4. Head ventrally convex, large ventrolateral pouches behind eyes in both sexes.

5. Pronotum trapezoidal. Longitudinal sulcus not reaching posterior lobe; its definition varies with the species.

${ }^{6}$ Carpintero, D. J, 1980. Nuevos Ectrichodiinae americanos (Insecta: Hemiptera: Reduviidae). Acta Sci. Entomol. 14: 1-33. 
6. All legs similar, unspined, slightly longitudinally carinate. Spongy fossa on protibia about one-seventh the length of the segment, about one-tenth on the mesotibia in all species.

7. All or most of the abdominal intersternal sutures crenatepunctate; sterna with well defined small circular depressions, the number varies with the species. Among the other genera only Daraxa (Daraxa) carioca has similar punctuations. For this reason the character is not considered of generic value.

Cricetopareis has been collected in Argentina, Brasil, Bolivia, and Paraguay. Should occur in Uruguay.

The species in Cricetopareis are predators. They occur in forested plains and mountains, under stones or bark and in hollow tree trunks. $C$. paraguaya flies during the daytime and can be collected on flowers where it feeds on true bugs and beetles. In the laboratory it feeds freely on scarabaeids, coreids, spiders, and isopods. Males of $C$. paraguaya and C. tucumana are attracted to artificial light, especially UV. Their bite is quite painful, causing a burning sensation that lasts for hours and inflammation that lasts several days.

Cricetopareis brasiliensis Carpintero and Maldonado, new species.

Male: Head mostly black; red orange - dorsally, ocellar callus, occiput, median dorsal stripe on neck; straw yellow - anterior half of tylus, ocelli, apex of antenniferous tubercle. Anterior lobe of pronotum light yellow, posterior lobe orange red. Scutellum black, lateral projections yellow basally and reddish apically. Remaining parts of thorax dark brown with blackish areas, shiny. Legs dark brown; tarsi yellow including pilosity. Hemelytra dull black, with reddish tinge on clavus, corium externally and base of veins; hind wings translucent, light brown, veins slightly darker. Abdomen dorsally and ventrally dark brown, shiny; connexivum along outer third shiny light yellow ventrally and dorsally.

A relatively small species. Head as wide as long; posterior lobe basally sloping upward to ocellar callus; ocellar callus strongly elevated, subspheroidal, the elliptical ocelli located anterolaterally. Eyes quite large, subpedunculate, well surpassing level of vertex, not reaching ventral margin of head (fig. 1,2,3). On lateral view tylus triangular, anterior and superior margins subequal, the inferior the longest; uppermost margin as seen from above as thick as base of $I$ antennal segment, with two shallow longitudinal striations almost to apex. Antenniferous tubercle close to anterior-internal margin of eye; thick, short, with a small lateral triangular projection. Genae and jugum grossly corrugate. Rostrum thick; I segment surpassing level of anterior margin of eye. First anten- 

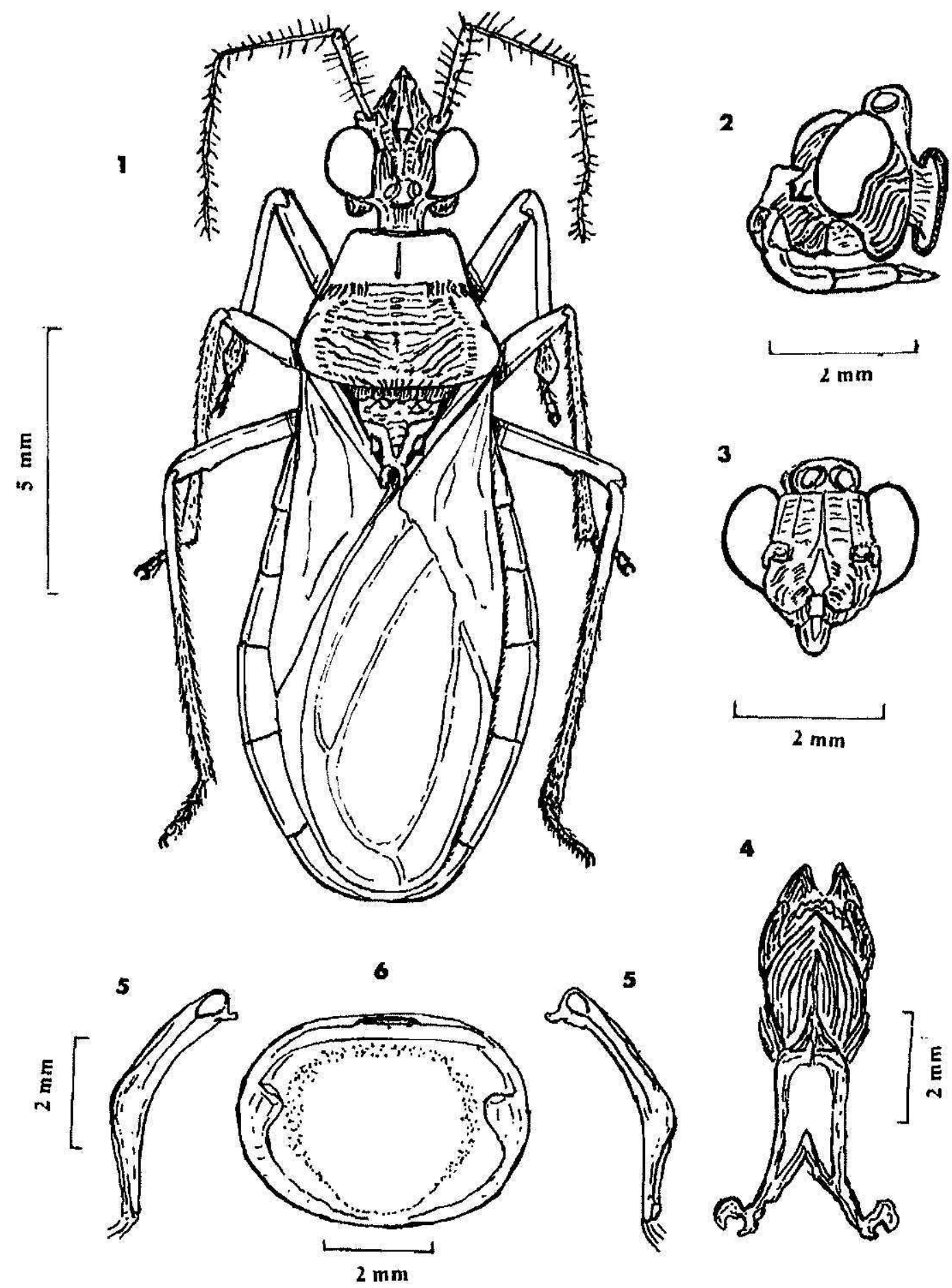

Plate I.-Cricetopareis brasiliensis, male holotype, 1. habitus, dorsal; 2. head, lateral; 3. head, frontal; 4. phallosome, extended, nearly flat; 5 . clasper, dorsal; 6 hypopygium, dorsal.

nal segment as in genus; II segment slightly curved; moderately abundant thicker vertical setae and thinner decumbent pilosity on all seg- 
ments, the setae twice as long as thickness of corresponding segment. Ventral surface of head with a longitudinal sulcus that posteriorly separates the gular pouches.

Pronotum trapezoidal, lateral margins straight; simple short collar; anterior lobe with shallow sulcus, surface smooth; posterior lobe with disc transversely wrinkled, paralateral sulci with short transverse carinae (fig. 1), lateral and posterior borders smooth. Scutellum triangular, carinate as in fig. 1; apical prongs contiguous basally, incurved, their apices close. Pleurae strongly rugose. Prosternum with deep stridulatory sulcus, $1+1$ sublateral sulci. Mesosternum with median depression that probably functions as an elongation of the stridulatory sulcus. Pro- and mesofemur with ventral surface feebly carinate, with small round elevations discernible at $60 \times$. Trochanters with a straight, stiff basal seta. Forewings almost reaching abdominal apex, hind wings reaching apex of VI tergum; apex of corial area reaching apex of $\mathrm{V}$ tergum.

Abdomen dorsally rugose. Crenation of sternal sutures: second and third complete, fourth and fifth feebly medially, strong laterally; sixth on lateral margins only. Sterna punctate, punctuations sparse medianly; seventh sternum uniformly punctate. Connexivum: ventrally smooth, shiny; dorsally smooth, shiny on outer third, inner two-thirds rugose. Spiracles oval.

Genitalia: apical process of hypopygium falciform, slightly developed, obsolete. Claspers smooth, slightly incurved on apical third, subbasally thickened, apex rounded, a small preapical digitiform appendix (fig. 5).

Head to base of neck 2.8, width 2.8, interocular space 1.2, width of eyes as seen from above 0.8 . Rostral segments: $1.6,1.2,0.5$; proportions: 1:0.75:0.31. Antennal segments: $1.8,2.3,0.8,0.6,0.6,0.4,0.4,0.5$; proportions: 1:1.27:0.44:0.33:0.33:0.22:0.22:0.27. Pronotum: length 9.8, greatest width 4.4. Total length of body $15.6 \mathrm{~mm}$.

Holotype - BRAZIL, Amazonia, Santarem; 8 XII 1963 (120); C. Marlier collector. Labeled "r. p. lateralis". Deposited in the Royal Institute of Natural Sciences, Tervuren, Belgium.

Because of its small size $C$. brasiliensis is close to $C$. boliviana. Differs from the latter by having larger eyes, tylus as an isosceles triangle, first rostral segment not reaching midlength of eye, area between eyes flattened, posterior lobe of pronotum rugose-striate, abdominal sterna sparsely punctuate along median line, pronotum bicolor. The type was compared with the other species in the genus.

\section{Key to males of Cricetopareis}

1. Length under $16 \mathrm{~mm}$........................................................ 2

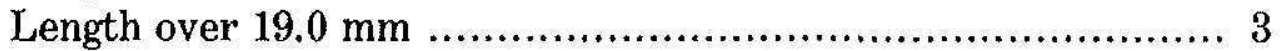

2. Tylus equilateral triangle. Pronotum smooth. 
Sternal punctuations uniformly distributed, abundant. $14.2 \mathrm{~mm}$ boliviana Breddin 1903 Tylus isoleceles triangle, basal margin the longest. Posterior lobe of pronotum rugose-striate. Sternal punctuations scarce on median third. $15.6 \mathrm{~mm}$ brasiliensis $\mathrm{n}$. $\mathrm{sp}$.

3. Tylus isosceles triangle, apically with a digitiform projection. Prongs of scutellum from separte and parallel to divergent. Sternal punctuations scarce, along margins only, medianly not punctate. $21.1 \mathrm{~mm}$ paraguaya Carpintero 1980 Tylus different. Prongs of scutellum from close throughout their length to close only apically

4. Tylus almost conical. Prongs of scutellum with apices only very close. Deeper sternal punctuations along margins of sclerite, middle third with few punctuations. $19.8 \mathrm{~mm}$.................. $t$. tucumana 1884) Tylus sealene triangular. Prongs of scutellum in contact along their length. Deep sternal punctuations throughout, middle third with more abundant punctuations except on VII. $22.8 \mathrm{~mm}$

tucumana orientalis Carpintero 1980

Genitalic key to males of Cricetopareis

1. Process of hypopygium obsolete, a mere crest-like elevation

Process of hypopygium developed brasiliensis n. sp

2. Process of hypopygium relatively short, conical, constricted at $2 / 3$ from base ............................................... tucumana s. lat. Process of hypopygium not conical, without constriction ........... 3

3. Process of hypopygium quadrangular, higher than wide. Claspers curved along apical 2/3, apex rounded ...................... boliviana Process of hypopygium trapezoidal, wide, short. Claspers angularly incurved at $2 / 3$ their length from base, apically spined . paraguaya

Key to females of Cricetopareis

1. Eyes, ocellar callus, and ocelli smaller than in male. Braquipterous or apterous .......................................................... 2 Eye, ocellar, callus, and ocelli almost or as in male. Alate; if braquipterous pads reaching at least IV tergum ...... tucumana orientalis

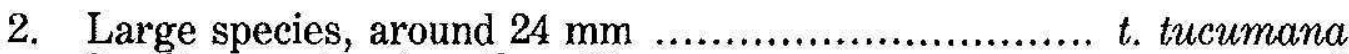
Smaller species, less than $20 \mathrm{~mm}$.................................... 3

3. Eyes, ocellar callus, and ocelli slightly smaller than in male. Wing pads not reaching IV tergum. Around $20 \mathrm{~mm}$............. boliviana Eyes, ocellar callus, and ocelli much smaller than in male. Braquipterous or apterous, if apterous, somewhat similar to females of Racelda. Around $16 \mathrm{~mm}$ paraguaya) 